\title{
Epigenetic Therapy of Cancer
}

\author{
Karmen M. Stankov ${ }^{1}$, Nebojša M. Pavlović2 ${ }^{2}$ Momir M. Mikov² \\ ${ }^{1}$ Clinical Center of Vojvodina, Faculty of Medicine, University of Novi Sad, Novi Sad, Serbia; \\ 2 Department of Pharmacology, Toxicology and Clinical Pharmacology, Faculty of Medicine, \\ University of Novi Sad, Novi Sad, Serbia
}

\section{SUMMARY}

Together with genetic alterations, aberrant epigenetic regulation of gene expression also plays a major role in the development of many diseases, including cancer. Overall, when compared to normal cells, the genome of malignant cells is characterized by global DNA hypomethylation and histone hypoacetylation. Considering the significance of DNA methylation and histone acetylation in the initiation and progression of human cancer, epigenetic modifications are identified as novel therapeutic targets. In contrast to genetic alterations, epigenetic changes in cancer are potentially reversible. This fact resulted in the development of pharmacologic inhibitors of DNA methyltransferases (DNMTs) and histone deacetylases (HDACs). These compounds can reverse epigenetic silencing of tumor suppressor genes by inducing the demethylation of DNA and histone acetylation, resulting in reactivation of these genes in tumor cells and restoration of crucial cellular pathways. However, it is still unclear whether the majority of HDAC inhibitors' effects are the result of alterations of histone acetylation patterns or changes in growth regulatory pathways deregulated by the increased acetylation of non-histone proteins. Although DNMT and HDAC inhibitors can be active as monotherapy, it is widely accepted that the most effective clinical application of epigenetic modulators may be in combination with other agents. Much remains to be elucidated about the epigenome, regarding its role and its dysregulation in cancer, and therefore future research is needed to provide sufficient information for optimization of epigenetic therapy in clinical practice.

Keywords: epigenetics; DNA methylation; acetylation; histone deacetylase; tumor; inhibitor

\section{INTRODUCTION}

The cells in a multicellular organism maintain different terminal phenotypes although they have nominally identical DNA sequences. This nongenetic cellular memory, which records the developmental and environmental signals, represents the fundamentals of epigenetics [1]. The definition of epigenetics has constantly evolved and now epigenetics is most often defined as "the changes happening on a chromosome without altering its DNA sequence, leading to a heritable and stable phenotype" [2]. Epigenetics refers to all controlled reversible processes that cause the changes in gene expression independent of DNA sequence alterations. DNA methylation and histone modification are considered the two main epigenetic mechanisms [3].

Given the complexity of eukaryotic genome due to necessity of storing large amounts of DNA within the nucleus, the mechanisms that maintain structure and function of genome are also complex. The structural organization of DNA into chromatin creates an environment that is generally repressive for gene transcription. However, chromatin is a highly dynamic structure that must be modified to accommodate the transcriptional machinery when gene 
expression is required, to facilitate DNA repair mechanisms, or to allow DNA replication [4]. DNA methylation and histone modification, as epigenetic mechanisms, regulate the access of the transcription machinery to their target genes, modulating transitions from condensed heterochromatin to relaxed euchromatin and vice versa. These mechanisms work synergistically to regulate the chromatin structure and to establish the precise pattern of gene expression, required for normal physiological cell functions and a wide variety of biological processes [5].

\section{DNA METHYLATION}

DNA methylation consists of the covalent addition of a methyl group to the DNA, predominantly to the 5' position of the cytosine next to guanine, also called a CpG dinucleotide. In contrast to the general underrepresentation of $\mathrm{CpGs}$ in the overall genome, a subset of $\mathrm{CpG}$ dinucleotides are clustered in small stretches of DNA called CpG islands, often located in or near the promoter region of genes. Approximately $60 \%$ of gene promoters contain CpG sites and methylation of $\mathrm{CpG}$ dinucleotides is an important epigenetic gene silencing mechanism [6]. Most methylation in the human genome occurs in the vast genomic areas with repetitive sequences, such as centromeres and transposon elements that are involved in chromosomal stability, $\mathrm{CpG}$ island shores, non-coding regions (i.e. enhancer regions and miRNAs), and gene bodies (silencing alternative transcription start sites). On the other hand, CpG islands are largely unmethylated in both expressing and non-expressing tissues under normal conditions [7].

DNA methyltransferases (DNMTs) are a family of enzymes responsible for DNA methylation. DNMTs transfer a methyl group from the methyl donor molecule S-adenosyl-Lmethionine to the carbon 5 of the cytosine [8]. There are three mammalian DNA methyltransferases, DNMT1, DNMT3A and DNMT3B. DNMT3A/B act as de novo methytransferases and are important for establishing DNA methylation patterns, whereas, DNMT1 acts as a maintenance enzyme, preserving existing methylation patterns after cell replication, and its deletion leads to apoptosis $[7,9]$.

Gene silencing can be induced by DNA methylation through several mechanisms. If promoter CpG islands are methylated, the corresponding gene is repressed directly due to a poor recognition by transcription factors and also due to recruitment of proteins involved in the chromatin remodeling, such as methyl-binding domain proteins (MBDs). Besides, apart from their methylation ability, DNMTs have additional roles in gene silencing, by acting as transcriptional repressors themselves, or by serving as binding scaffolds for transcriptional repressors, histone deacetylases and histone methyltransferases [10].

\section{HISTONE MODIFICATIONS}

Besides direct manipulation of DNA, modifications of the core histones also play important roles in epigenetic regulation. Histones are a fundamental component of nucleosomes, the basic packaging unit of nuclear DNA. Each nucleosome consists of an octamer of histones $\mathrm{H} 2 \mathrm{~A}, \mathrm{H} 2 \mathrm{~B}, \mathrm{H} 3$, and $\mathrm{H} 4$ variants forming a globular core around which about 146 base pairs of DNA are wrapped. Internucleosomal interactions further package nuclear DNA into the chromatin fiber. The histone component of chromatin functions to organize the DNA as well as to provide mechanisms for regulating transcription factors' accessibility and gene expression. Condensed chromatin, in which the nucleosomes are tightly compacted, may not be as easily accessible to the transcriptional machinery as chromatin in which the histones and the DNA are not as tightly packed [11]. The amino-terminal tails of histones that protrude out of the nucleosome are subject to various post-translational modifications, including acetylation, methylation, phosphorylation, ubiquitination, sumoylation, ADP-ribosylation, glycosylation, biotinylation and carbonylation. The best characterized histone modification is histone acetylation, which is regulated by the reciprocal activity of histone acetyltransferases (HATs) and histone deacetylases (HDACs) [10].

Acetylation of the $\varepsilon$-amino group of lysine residues within histones modulates the DNA function in two major ways. Firstly, acetylation of lysine residues neutralizes the positive charge of histone tails, which decreases the strength of interaction between histones and DNA, leading to alterations in chromatin packaging. Secondly, the modified lysine residues can act as docking sites for binding proteins, thereby recruiting additional chromatin modifying and/or transcriptional modulating proteins [12]. Therefore, histone acetylation generally refers to an open 
and transcriptionally active chromatin state, whereas histone deacetylation is associated with chromatin condensation and transcriptional repression.

In humans, eighteen different HDACs have been identified and divided into two families on the basis of their catalytic mechanism of action and sequence homology. The classical HDAC family consists of proteins with a highly conserved catalytic domain that require a zinc cation for catalytic activity. These proteins are further sub-divided into three classes based on sequence similarities: class I (HDACs 1, 2, 3 and 8), class II (HDACs 4, 5, 6, 7, 9 and 10) and class IV (HDAC11) [13]. The HDACs are not redundant in their biological activity. Class I HDACs have an important role in cell proliferation, whereas class II HDACs appear to act more in tissue-specific functions [14]. The second family of HDACs named sirtuins (class III) differ from class I, II, and IV HDACs in three respects: they are homologous to yeast Sir2 rather than Rpd3 or Hda1, they require $\mathrm{NAD}^{+}$for activity, and they are refractory to inhibition by pan-HDAC inhibitors such as trichostatin A [15].

As the name indicates, histones are the major substrate class for HDACs. In addition to histones, HDACs target a wide range of non-histone proteins, including many transcription factors (for example, the tumor suppressor p53), a-tubulin, heat shock protein 90 (Hsp90), and various signaling proteins. Acetylation of Hsp90 impairs its ability to form complexes with client proteins, such as oncogenic - Her2/neu and c-Raf and a few antiapoptotic proteins, ultimately leading to their proteasomal degradation [16].

\section{EPIGENETIC ALTERATIONS IN CANCER}

Significant advances have been made recently in understanding of tumor cell biology and carcinogenesis and insights into these complex intracellular processes have exposed many novel cancer targets. It has been demonstrated that intracellular signaling molecules are modulated by external factors, such as epigenetic changes, oncogenic mutations, molecular chaperones, and ubiquitin-proteasome pathways [17]. In contrast to traditional anticancer drugs that directly interfere with mitosis, DNA synthesis, and repair systems, a new class of chemotherapeutic agents induces tumor growth inhibition mostly by exploiting cellular signaling mechanisms. The increased knowledge of the cancer genome and epigenome, and the introduction of multiple new technologies in cancer research has significantly improved the drug discovery process, leading to key success in targeted cancer therapeutics, including tyrosine kinase inhibitors (TKIs) [18]. The studies of receptor tyrosine kinases and their role in malignant transformation are already translated from the preclinical level to clinical studies. Starting from 1996, when the first non-selective TKI imatinib mesylate revolutionized the management of patients with chronic myeloid leukemia (CML), new emerging more-selective TKIs have been synthesized and approved for clinical use [19]. Similarly, the progress in deciphering the epigenetic regulatory mechanisms in normal and malignant cells have led to the improvement of tumor therapy in clinical practice.

Together with genetic alterations, aberrant epigenetic regulation of gene expression also plays a major role in the development of many diseases, including cancer. Unlike mutations and other structural alterations of DNA, epigenetic modifications, as the early event in tumorigenesis, can be reversed [5]. Overall, when compared to normal cells, the genome of malignant cells is characterized by global DNA hypomethylation and chromatin hypoacetylation, and gene-specific hypo- and hypermethylation as well [20].

DNA methylation in cancer is currently the best characterized epigenetic aberration. It is a relatively stable modification that occurs in the context of CpG dinucleotides in mammalian cells. As mentioned earlier, the presence of $\mathrm{CpG}$ sites within the genome is irregular, with some regions containing a high frequency of $\mathrm{CpG}$ dinucleotides ( $\mathrm{CpG}$ islands), that are resistant to de novo methylation in normal cells, in contrast to areas where this dinucleotide is underrepresented. Distinct methylation patterns are established during embryogenesis and are mitotically heritable. The maintenance of normal DNA methylation patterns is disrupted in cancer, where $\mathrm{CpG}$ islands become susceptible to methyltransferase activity and $\mathrm{CPG}$ poor regions undergo hypomethylation during transformation. Global hypomethylation of cellular DNA might result in genomic and chromosomal instability, including the possible activation of oncogenes [21]. Besides a general genomic hypomethylation, malignant cells are also characterized by local hypermethylation of tumor 
suppressor genes that leads to aberrant silencing of these genes [22]. Consistent with this, it was demonstrated that the overall levels of genomic 5 -methylcytosine in a tumor genome is reduced as compared with those in normal tissues. On the other hand, many known tumor suppressor genes, such as MLH1 in colon cancer, BRCA1 in breast cancer, DAPK1 in chronic lymphocytic leukemia, or p16INK4a in head and neck cancer and lung cancer, were found to be hypermethylated and epigenetically repressed [23].

Aberrant tumor suppressor gene DNA methylation in human cancer cells is cooperatively maintained by DNMT1 and DNMT3B. It has become apparent that more genes might be inactivated by epigenetic silencing as they are by genetic aberrations [24]. While DNMTs are in the same general class of enzymes and share similarities within their catalytic domains, their roles in tumorigenesis may differ. DNMT3A deletion may promote cancer progression, yet DNMT3B deletion may in fact inhibit oncogenesis by liberating previously silenced tumor-suppressor genes [7]. DNMTs cooperate to silence genes and promote cell survival in at least some human cancers and overexpression of DNMT1/3A/3B is common in lung, breast, prostate and breast cancer, as well as many other malignancies [9].

Alterations of the normal histone modification pattern are also known to contribute to carcinogenesis. The impact of histone acetylation is the best studied mechanism. Disruption of the functional acetylation profile can be triggered by different mechanisms [5]. Overexpression of HDACs, leading to a general hypoacetylation, has been observed in both hematological malignancies and solid tumors. Altered expression of individual HDACs in malignant cells has been shown to depend on tumor type and tissue of its origin. Some studies demonstrate that high expression of individual HDACs correlates with advanced stage of disease and poor prognosis [25].

Abnormal HDAC activities have been shown to play major roles in mechanisms regulating a number of the cancer hallmarks, mainly the tumor suppressor silencing, but also cell cycle control and growth signaling, differentiation, angiogenesis, cell adhesion, and metastasis. Aberrant recruitment of HDACs has been correlated with decreased levels of acetylated histones at specific genes associated with the control of cell growth. Particular genes involved in tumor suppression and cell growth regulation that are known to be silenced through HDACmediated epigenetic mechanisms include p21, p27, p16, p19, among many others [26].

The mechanisms by which HDAC are involved in tumorigenesis are still to be elucidated. Today, it is known that histone hypoacetylation is the characteristics of most cancers. Overexpression of specific HDACs occurs in many cancer types, and the growth of cell lines derived from these tumors is suppressed by small interfering RNA-mediated knockdown of the overexpressed HDAC. In addition, elevated expression of HDACs may block the function of tumor suppressor proteins such as p53. Finally, besides affecting the chromatin structure and regulating gene expression and genomic stability, HDACs target oncogenic regulators such as Hsp90 that are important for cancer development [16].

Considering the importance of DNA methylation and histone acetylation in the initiation and progression of human cancer, these mechanisms are identified as novel therapeutic targets. In contrast to genetic alterations, epigenetic changes in cancer are potentially reversible. This resulted in the development of pharmacologic inhibitors of DNA methylation and histone deacetylation. By inducing demethylation of DNA and histone acetylation, these compounds can reverse the epigenetic silencing of tumor suppressor genes, resulting in reactivation of these genes in tumor cells and restoration of crucial cellular pathways [10].

\section{DNA METHYLTRANSFERASE INHIBITORS}

Demethylating agents are relatively new class of anticancer drugs that alter DNA methylation through DNMT inhibition. These drugs can be divided into two major structural groups nucleoside and non-nucleoside analogs.

The most extensively studied DNMT inhibitors are the nucleoside analogs 5-azacytidine (Vidaza ${ }^{\circledast}$ ) and 5-aza-2'-deoxycytidine or decitabine (Dacogen ${ }^{\circledast}$ ), which were approved by FDA and EMA for the treatment myelodysplastic syndrome (MDS), although they have also shown promising results in patients with acute myeloid leukemia (AML) and chronic myelomonocytic leukemia (CMML) in several clinical studies. Decitabine and 5-azacytidine were initially developed as chemotherapeutic agents, prior to the discovery of their demethyl- 
ating activity. The recognition of the epigenetic activities of these drugs resulted in the clinical use of much lower doses, especially in the field of hematological malignancies [10].

5-azacytidine and 5-aza-2'-deoxycytidine (decitabine) are two cytidine analogs in which the carbon atom in position 5 is replaced by a nitrogen atom and linked to a ribose or a deoxyribose, respectively. When these analogs are transported into cells by hCNT1, they undergo phosphorylation followed by conversion into their triphosphorylated active forms. The ribose analogs are incorporated both into RNA and DNA after deoxy-conversion, whereas the deoxyribose analogs are incorporated only into DNA. To exert their activity, these nucleoside analogs are incorporated into DNA in place of the natural base cytosine during DNA replication, and are therefore only active during $S$ phase, allowing certain specificity towards rapidly proliferating cancer cells [27]. 5-azacytidine and 5-aza-2'-deoxycytidine are metabolized intracellularly to 5-aza-2'-deoxycytidine-triphosphate, which is incorporated into DNA in place of 2'-deoxycytidine-triphosphate. This results in the covalent binding of DNMT1, DNMT3A and DNMT3B to modified DNA, trapping and inhibition of DNMT activity and degradation of these enzymes. This depletes DNMTs and thereby prevents the methylation of the daughter DNA strand following cell division leading to the reversal of silencing of tumor suppressor-like molecules [28].

Reactivation of silenced tumor suppressor genes is the main mechanism by which DNMT inhibitors suppress growth and induce differentiation of human tumor cells. Other mechanisms, by which nucleoside DNMT inhibitors act to kill cells, have also been reported. For example, in leukemic cells, decitabine can increase the expression of several genes that do not contain a $\mathrm{CpG}$ island, and it can also induce the DNA double strand breaks [29]. Recently, it has been reported that 5-azacytidine and decitabine can induce apoptosis in neoplastic mast cells through re-expression of Fas receptor [30]. It has also been shown that 5-azacytidine treatment leads to apoptosis of both myeloid precursor PC-MDS cells and leukemia K562 cells, mainly through the induction of Bak mRNA expression [31]. Furthermore, it has been demonstrated that decitabine increases the reactive oxygen species (ROS) generation leading to apoptosis, which can be blocked by $\mathrm{N}$-acetyl cysteine, a ROS scavenger [32].
A major disadvantage of 5-azacytidine and 5-aza-2'-deoxycytidine is their instability in neutral aqueous solution. Following their discovery, several other analogs have been synthesized, among them 5,6-dihydro-5-azacytidine and 5-fluoro-2'-deoxycytidine, which demonstrated high toxicity in several preclinical studies. Zebularine is a DNMT inhibitor, which is very stable, enabling the oral administration of the drug. In addition, this cytidine analog is minimally toxic both in vitro and in vivo, but further novel information related to a possible clinical development of zebularine need to be published to support these results [10].

In order to improve the pharmacokinetic profile of the first generation DNMT inhibitors, an elaidic acid ester of 5-azacytidine, CP-4200, and SGI-110 (formerly S-110) that acts as a decitabine prodrug, have been synthesized. SGI-110 is a dinucleotide decitabine-p-deoxyguanosine, as stable as decitabine in aqueous solution, but more resistant to cytidine deaminase. Both of these prodrugs showed relatively more potent tumoricidal activity in cell lines and animal models and await clinical investigation [33].

The main documented toxicities of nucleoside DNMT inhibitors were the myelosuppression, including neutropenia and thrombocytopenia, as well as nausea and vomiting [7]. In addition to their instability, nucleoside analogs may not be the ideal candidates for epigenetic therapy since they become incorporated into DNA and are thus cytotoxic. It has been speculated that the use of nucleoside analogs may result in the formation of secondary tumors that arise due to chromosomal instability after pertinent changes in DNA methylation [34]. The toxicity of nucleoside analogs, associated with their incorporation into DNA, resulted in the search for non-nucleoside DNMT inhibitors, whose mechanism does not rely on DNA incorporation.

Some DNMT inhibitors of various origins and structures have been described during the last years and most of these compounds have already demonstrated a biological activity against other targets than DNMTs. For procainamide and its ester analog procaine that have been used as antiarrhythmic and anesthetic agents respectively, and for the antihypertensive drug hydralazine, DNMT inhibitory effects have been discovered through their secondary effects. Several natural compounds have also been shown to exert the DNA demethylating effects, such as some flavonoids, psammaplin A, 
curcumin. One of the most studied flavonoids with DNMT inhibitory activity is epigallocatechin-3-O-gallate (EGCG), the main polyphenol of the green tea with established preventive antitumor properties. Synthetic compound RG108, phthalimido-L-tryptophan, is a DNMT inhibitor found by virtual screening on DNMT1. SGI-1027 is a lipophilic quinoline inhibiting DNMT1, 3A and 3B that initially showed the antitumor activities. MG98 is an antisense oligonucleotide that specifically inhibits DNMT1 mRNA and that has been tested in clinical trials [33]. Several recent patents have described new progress in the area of non-nucleoside DNMT inhibitors. The series of compounds based on (L)-S-adenosyl-L-homocysteine (L-SAH) have been designed and synthesized as inhibitors of human DNMT enzymes [35]. As none of the described non-nucleoside inhibitors have entered clinical development yet, there is still a long way to go before the identification of novel, selective, non-nucleoside DNMT inhibitors [33]

\section{HISTONE DEACETYLASE INHIBITORS}

Given that global histone hypoacetylation and overexpression of specific HDACs are the characteristics of most cancers, which can be reversed, targeting histone deacetylases provides a good rationale for anticancer therapy. By inhibiting histone deacetylation, HDAC inhibitors cause the accumulation of acetylated histones, thereby inducing an open chromatin conformation, leading to increased transcription of previously silenced genes [10].

Many mechanisms by which HDAC inhibitors exert antitumor effects have been described. HDAC inhibitors activate both intrinsic and extrinsic apoptotic pathway and they regulate the activity of tumor suppressors p53 and p73 as important inducers of apoptosis. HDAC inhibitors also target DNA-repairing enzymes involved in induction of apoptosis and thus the acetylation of Ku70 releases Bax, allowing it to translocate to the mitochondrial outer membrane and initiate apoptosis. Furthermore, HDAC inhibitors modulate the activity of chaperone protein $\mathrm{Hsp} 90$ by its acetylation and this impairs the ability of Hsp90 to form complexes with client proteins, such as oncogenic proteins Her2/neu and c-Raf, ultimately leading to their proteasomal degradation. HDAC inhibitors can also induce apoptosis of malignant cells through the generation of ROS that precedes the loss of mitochondrial outer membrane potential [25]. Hyper-acetylation of the centromere induced by HDAC inhibitors induce the heterochromatin protein release, resulting in abnormal chromosomal segregation, which leads to aberrant mitosis and apoptosis [36]. In addition to well-known anti-proliferative effects of HDAC inhibitors, additional anti-inflammatory properties of these drugs have been described recently. This dual efficacy of HDAC inhibitors is highly attractive, since chronic inflammation is associated with an increased risk of developing carcinomas [37]. It is still unclear whether the majority of HDAC inhibitors' effects are the result of alterations of histone acetylation patterns or changes in growth regulatory pathways by increased acetylation of non-histone proteins.

Multiple HDAC inhibitors are currently being tested in preclinical and clinical studies, and vorinostat or suberoylanilide hydroxamic acid (SAHA) is the most advanced in development to date. Vorinostat $\left(Z^{2}\right.$ linza $\left.{ }^{\circledR}\right)$ is a hydroxamate HDAC inhibitor approved by FDA in 2006 for therapy of cutaneous T-cell lymphoma (CTCL) and has been assessed in multiple clinical trials for various solid and hematological malignancies. Vorinostat is an oral drug and is considered a pan-selective inhibitor since it inhibits all known zinc dependent HDACs. Vorinostat, like other HDAC inhibitors, induces the cell cycle arrest, differentiation and/or apoptosis in an extremely wide range of malignant cell types, including those derived from hematological malignancies and the common solid cancers, e.g., breast, colon, lung and prostate [14]. Significant adverse events noted for vorinostat were diarrhea, hypercholesterolemia, and anemia. Although generally more tolerable than conventional chemotherapeutic agents, fatigue has been severe enough to cause discontinuation of HDAC inhibitors in up to $30 \%$ of patients [38].

Both naturally existing and synthetic HDAC inhibitors have been characterized. These compounds are structurally heterogeneous, and based on their chemical structure, HDAC inhibitors can be categorized into four subtypes: short-chain fatty acids, hydroxamic acids, benzamides and cyclic peptides [26].

The group of short-chain fatty acid includes the butyric acid, sodium butyrate, phenylbutyrate, valproic acid and a prodrug AN-9 [25]. Valproic acid is widely used as an anticonvulsant and mood-stabilizing drug, and has 
also been shown to act as HDAC inhibitor. Its HDAC inhibitory potency is several orders of magnitude lower than other clinically relevant HDAC inhibitors and the doses of valproic acid used in clinical trials for various solid and hematological malignancies are up to 5 times larger than the doses utilized for epilepsy [39].

The hydroxamic acid-based inhibitors are the most potent reported to date. Their high potency can be attributed to the strong chelating affinity of the hydroxamic acid to the zinc cation in the active site. In addition, it is proposed that the hydroxamic acid can form the hydrogen bonds with active site hydrophilic residues such as tyrosine and histidine. The discovery of the natural product trichostatin A, a nanomolar HDAC inhibitor, has stimulated great efforts in identifying hydroxamic acid-based inhibitors with better pharmacological properties. As a result, a broad set of inhibitors with potent HDAC activities has been identified, including vorinostat (SAHA), panobinostat (LBH589), belinostat (PXD101) and droxinostat [26]. They all mimic the lysine substrate and chelate essential zinc ion in the enzymatic center of class I and II HDACs. In this group SK-7041 and SK-7068 have been shown to selectively inhibit only HDAC1 and 2 [40], whereas tubacin is a specific inhibitor of HDAC6 [41].

A major shortcoming of the first generation of hydroxamic acid-based HDAC inhibitors is their poor oral bioavailability, which has stimulated great efforts in identifying compounds with alternative zinc binding groups and with better pharmacokinetic properties. A series featuring sulfamates as the zinc binding group that have shown selectivity for HDAC6, have been synthesized [42]. Furthermore, quisinostat (JNJ-26481585) is relatively new pyrimidyl-hydroxamate HDAC inhibitor identified in an in vivo screen of a relatively small number of active compounds and is under clinical development. Besides improved pharmacokinetic properties, this compound exhibits also a prolonged in vivo pharmacodynamic effect [43].

Benzamides are a promising class of HDAC inhibitors, as they avoid the metabolic lability and phase II conjugation issues associated with hydroxamic acids. Benzamide HDAC inhibitors, entinostat (SNDX-275 or MS-275), mocetinostat (MGCD0103) and tacedinaline (CI-994) are currently in clinical development. The mechanism of HDAC inhibition is thought to involve the interaction of the two substituted amides with the zinc cation at the active site of the enzyme [9]. Recently, a series of thiophene-substituted analogues of the benzamide HDAC inhibitors and aminophenyl benzamide derivatives have been synthesized. In addition to enhanced potency, presumably due to additional binding contacts within the internal cavity of HDACs, these substituted compounds showed increased selectivity towards malignant cells and enhanced selectivity towards HDAC1 and 2, which play a critical role in cell growth and survival of some cancer types $[44,45]$.

The fourth group, cyclic peptides, includes depsipeptide (romidepsin, FK228, FR901228), apicidin and trapoxin. Natural product cyclopeptide and cyclodepsipeptide HDAC inhibitors are of considerable interest, and although numerous potent natural HDAC inhibitors have been described, only one, depsipeptide, is in clinical development. Depsipeptide is a prodrug, activated in cells due to reduction of the disulfide bond to thiol, which enters the active site of HDAC and chelates the zinc ion [46]. Apicidin is a reversible HDAC inhibitor at low nanomolar concentrations, bearing an alkylketone residue that is supposed to chelate the catalytic HDAC zinc ion. Trapoxin is closely related to apicidin, and irreversibly inactivates HDAC by covalent interaction between its epoxide group and the HDAC catalytic site [10]. The cyclic tetrapeptides appear to have some selectivity for class I HDACs, which have been strongly implicated in cancer development. However, there is insufficient in vivo antitumor efficacy data, most likely resulting from metabolic instability of these molecules [26].

Crystallographic studies have shown that the catalytic site of HDACs contains a zinc ion that is responsible for the transfer of the acetyl group. The lysine groups of histones reach this catalytic site through a long hydrophobic tunnel. The amino acid sequence of different isoforms of HDAC shares high homology at the active site and the lysine tunnel. Immediately adjacent to the tunnel is a shallow hydrophobic pocket, which is quite distinct among different classes of HDAC enzymes [26]. Despite their structural distinctiveness, HDAC inhibitors are generally considered to share common pharmacophore that include three key motifs, a "war-head" such as hydroxamic acid that interacts with the zinc ion in the active site, a hydrophobic group (cap) for protein recognition and interaction, and a linker about $10 \AA$ long, connecting the cap and the war-head (Figure 1) [47]. 


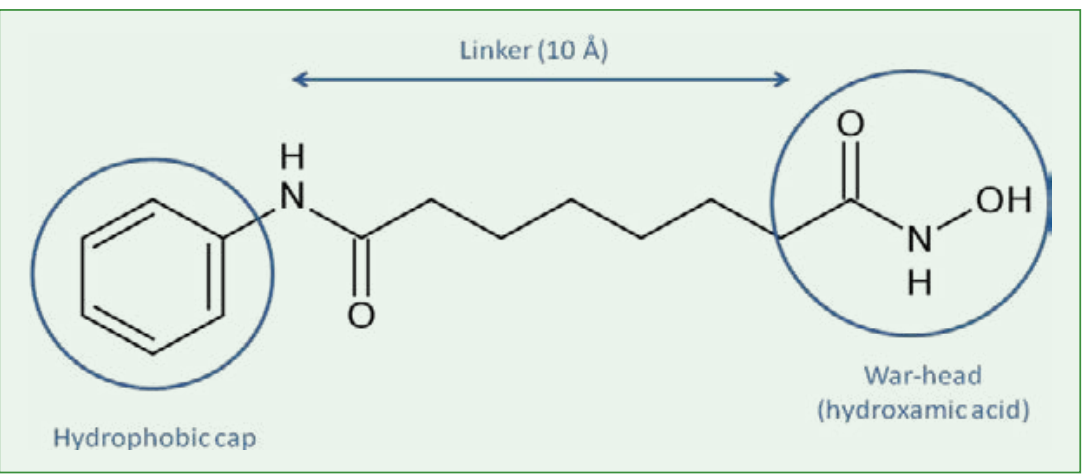

Figure 1. The chemical structure of vorinostat (SAHA). Pharmacophore of HDAC inhibitors include three key motifs: a hydrophilic war-head that interacts with the zinc ion in the active site of the enzyme, hydrophobic cap for protein recognition and interaction, and a linker that connects the cap and the war-head.

\section{CONCLUSIONS}

Although DNMT and HDAC inhibitors can be active as monotherapy, it is widely accepted that the most effective clinical application of epigenetic modulators may be in combination with other agents. The synergism between demethylating agents and HDAC inhibitors in vitro makes the combined treatment with DNMT and HDAC inhibitors a promising epigenetic therapy. It is considered that epigenetic agents may enhance the sensitivity to conventional chemotherapeutic agents since DNA strands are better exposed to intercalation or genotoxic damage when chromatin is relaxed by epigenetic drugs. Most current clinical trials are focused on DNMT or HDAC inhibitors in combination with other agents, and these combinations are mostly based on empirical knowledge. Future clinical studies should focus on combinations with a strong underlying mechanistic rationale.

Despite the encouraging results of the use of DNMT and HDAC inhibitors in preclinical and clinical studies, there are several challenges that must be overcome for the success of epigenetic therapy in the clinical practice. Significant issues for epigenetic therapy include the toxicity of epigenetic agents, optimal selectivity profile especially for HDAC inhibitors, identification of robust biomarkers to select the responsive patients and to monitor the pharmacodynamic response, and the optimal selection of combinations of epigenetic drugs with other agents. Despite intensive research in the field of epigenomic, much remains to be elucidated about the epigenome, regarding its role and its dysregulation in cancer, and therefore future research is needed to provide sufficient information for optimization of epigenetic therapy.

\section{ACKNOWLEDGEMENTS}

This work was supported by the Ministry of Education, Science and Technological Development, Republic of Serbia, project No. 41012.

\section{Conflict of Interest Statement}

The authors declare that there are no conflicts of interest.

\section{REFERENCES}

1. Bonasio R, Tu S, Reinberg D. Molecular signals of epigenetic states. Science. 2010; 330(6004):612-6.

2. Berger SL, Kouzarides T, Shiekhattar R, Shilatifard A. An operational definition of epigenetics. Genes Dev. 2009; 23(7):781-3.

3. Kouzarides T. Chromatin modifications and their function. Cell. 2007; 128(4):693-705.

4. Li B, Carey M, Workman JL. The role of chromatin during transcription. Cell. 2007; 128(4):707-19.

5. Seidel C, Florean C, Schnekenburger M, Dicato M, Diederich M. Chromatin-modifying agents in anti-cancer therapy. Biochimie. 2012; 94(11):2264-79.

6. Bird A. DNA methylation patterns and epigenetic memory. Genes Dev. 2002; 16(1):6-21.

7. Ho AS, Turcan S, Chan TA. Epigenetic therapy: use of agents targeting deacetylation and methylation in cancer management. Onco Targets Ther. 2013; 6:223-32.

8. Portela A, Esteller M. Epigenetic modifications and human disease. Nat Biotechnol. 2010; 28(10):1057-68.

9. Ganesan A, Nolan L, Crabb SJ, Packham G. Epigenetic therapy: histone acetylation, DNA methylation and anti-cancer drug discovery. Curr Cancer Drug Targets. 2009; 9(8):963-81.

10. Hellebrekers DM, Griffioen AW, van Engeland M. Dual targeting of epigenetic therapy in cancer. Biochim Biophys Acta. 2007; 1775(1):76-91.

11. Hager GL, McNally JG, Misteli T. Transcription dynamics. Mol Cell. 2009; 35(6):741-53.

12. Taverna SD, Li H, Ruthenburg AJ, Allis CD, Patel DJ. How chromatin-binding modules interpret histone modifications: lessons from professional pocket pickers. Nat Struct Mol Biol. 2007; 14(11):1025-40

13. Zhang Y, Fang H, Jiao J, Xu W. The structure and function of histone deacetylases: the target for anti-cancer therapy. Curr Med Chem. 2008; 15(27):2840-9.

14. Marks PA, Breslow R. Dimethyl sulfoxide to vorinostat: development of this histone deacetylase inhibitor as an anticancer drug. Nat Biotechnol. 2007; 25(1):84-90.

15. Peng L, Yuan Z, Ling H, Fukasawa K, Robertson K, Olashaw N, et al. SIRT1 deacetylates the DNA methyltransferase 1 (DNMT1) protein and alters its activities. Mol Cell Biol. 2011; 31(23):472034.

16. Walkinshaw DR, Yang XJ. Histone deacetylase inhibitors as novel anticancer therapeutics. Curr Oncol. 2008; 15(5):237-43. 
17. Ma WW, Adjei AA. Novel agents on the horizon for cancer therapy. CA Cancer J Clin. 2009; 59(2):111-37.

18. Stankov K, Bogdanović G, Popović S. Tyrosine kinases in etiopathogenesis and therapy of malignant diseases - C-kit activating mutations. Med Pregl. 2010; 63(5-6):380-6.

19. Stankov K, Stankov S, Popović S. Translational research in complex etiopathogenesis and therapy of hematological malignancies: the specific role of tyrosine kinases signaling and inhibition. Med Oncol. 2009; 26(4):437-44.

20. Stankov K. Genetski i epigenetski faktori u razvoju maligniteta. Nova saznanja u oblasti karcinogeneze. In: Pejin D, editor. Život sa karcinogenima. Beograd: Akademija medicinskih nauka Srpskog lekarskog društva; 2010. p.7-28.

21. Taberlay PC, Jones PA. DNA methylation and cancer. In: Gasser SM, Li E, editors. Epigenetics and Disease: Pharmaceutical Opportunities. Basel: Springer; 2011. p.1-23.

22. Robertson KD. DNA methylation and human disease. Nat Rev Genet. 2005; 6(8):597-610.

23. Park YJ, Claus R, Weichenhan D, Plass C. Genome-wide epigenetic modifications in cancer. In: Gasser SM, Li E, editors. Epigenetics and Disease: Pharmaceutical Opportunities. Basel: Springer; 2011. p.25-49.

24. Herman JG, Baylin SB. Gene silencing in cancer in association with promoter hypermethylation. $\mathrm{N}$ Engl J Med. 2003; 349(21):2042-54.

25. Wanczyk M, Roszczenko K, Marcinkiewicz K, Bojarczuk K, Kowara M, Winiarska M. HDACi going through the mechanisms. Front Biosci. 2011; 16:340-59.

26. Atadja PW. HDAC inhibitors and cancer therapy. In: Gasser SM, Li E, editors. Epigenetics and Disease: Pharmaceutical Opportunities. Basel: Springer; 2011. p.175-95.

27. Momparler RL. Pharmacology of 5-Aza-2'deoxycytidine (decitabine). Semin Hematol. 2005; 42(3 Suppl 2):S9-16.

28. Ghoshal K, Datta J, Majumder S, Bai S, Kutay H, Motiwala T, Jacob ST. 5-Aza-deoxycytidine induces selective degradation of DNA methyltransferase 1 by a proteasomal pathway that requires the KEN box, bromo-adjacent homology domain, and nuclear localization signal. Mol Cell Biol. 2005; 25(11):4727-41.

29. Nabbi A, Satpathy S, Riabowol K. Demethylating agents as epigenetic anticancer therapeutics. Curr Cancer Ther Rev. 2013; 9(1):24-33.

30. Ghanim V, Herrmann H, Heller G, Peter B, Hadzijusufovic E, Blatt K, et al. 5-azacytidine and decitabine exert proapoptotic effects on neoplastic mast cells: role of FAS-demethylation and FAS re-expression, and synergism with FAS-ligand. Blood. 2012; 119(18):4242-52.

31. Stankov K, Bogdanovic G, Kojic V, Stankov S, Jojic $\mathrm{N}$, Popovic $\mathrm{L}$, et al. Expression analysis of genes involved in epigenetic regulation and apoptosis in human malignant haematopoietic cell lines treated with 5-azacytidine. J BUON. 2011; 16(1):116-22.

32. Shin DY, Park YS, Yang K, Kim GY, Kim WJ, Han MH, et al. Decitabine, a DNA methyltransferase inhibitor, induces apoptosis in human leukemia cells through intracellular reactive oxygen species generation. Int J Oncol. 2012; 41(3):910-8.
33. Gros C, Fahy J, Halby L, Dufau I, Erdmann A, Gregoire JM, et al. DNA methylation inhibitors in cancer: recent and future approaches. Biochimie. 2012; 94(11):2280-96.

34. Eden A, Gaudet F, Waghmare A, Jaenisch R. Chromosomal instability and tumors promoted by DNA hypomethylation. Science. 2003; 300(5618):455.

35. Isakovic L, Saavedra OM, Llewellyn DB, Claridge $\mathrm{S}$, Zhan L, Bernstein N, et al. Constrained (I-)-S-adenosyl-l-homocysteine (SAH) analogues as DNA methyltransferase inhibitors. Bioorg Med Chem Lett. 2009; 19(10):2742-6.

36. Taddei A, Maison C, Roche D, Almouzni G. Reversible disruption of pericentric heterochromatin and centromere function by inhibiting deacetylases. Nat Cell Biol. 2001; 3(2):114-20.

37. Glauben R, Sonnenberg E, Zeitz M, Siegmund B. HDAC inhibitors in models of inflammation-related tumorigenesis. Cancer Lett. 2009; 280(2):154-9.

38. Federico M, Bagella L. Histone deacetylase inhibitors in the treatment of hematological malignancies and solid tumors. J Biomed Biotechnol. 2011; 2011:475641.

39. Khan N, Jeffers M, Kumar S, Hackett C, Boldog F, Khramtsov N, et al. Determination of the class and isoform selectivity of small-molecule histone deacetylase inhibitors. Biochem J. 2008; 409(2):581-9.

40. Park JH, Jung Y, Kim TY, Kim SG, Jong HS, Lee JW, et al. Class I histone deacetylase-selective novel synthetic inhibitors potently inhibit human tumor proliferation. Clin Cancer Res. 2004; 10(15):5271-81.

41. Haggarty SJ, Koeller KM, Wong JC, Grozinger CM, Schreiber SL. Domain-selective small-molecule inhibitor of histone deacetylase 6 (HDAC6) mediated tubulin deacetylation. Proc Natl Acad Sci USA. 2003; 100(8):4389-94.

42. Wahhab A, Smil D, Ajamian A, Allan M, Chantigny $\mathrm{Y}$, Therrien $\mathrm{E}$, et al. Sulfamides as novel histone deacetylase inhibitors. Bioorg Med Chem Lett. 2009; 19(2):336-40.

43. Arts J, King P, Marien A, Floren W, Belien A, Janssen L, et al. JNJ-26481585, a novel "second-generation" oral histone deacetylase inhibitor, shows broad-spectrum preclinical antitumoral activity. Clin Cancer Res. 2009; 15(22):6841-51.

44. Moradei OM, Mallais TC, Frechette S, Paquin I, Tessier PE, Leit SM, et al. Novel aminophenyl benzamide-type histone deacetylase inhibitors with enhanced potency and selectivity. J Med Chem. 2007; 50(23):5543-6.

45. Mahipal, Tanwar OP, Karthikeyan C, Moorthy NS, Trivedi P. 3D QSAR of aminophenyl benzamide derivatives as histone deacetylase inhibitors. Med Chem. 2010; 6(5):277-85.

46. Furumai R, Matsuyama A, Kobashi N, Lee KH, Nishiyama M, Nakajima H, et al. FK228 (depsipeptide) as a natural prodrug that inhibits class I histone deacetylases. Cancer Res. 2002; 62(17):4916-21.

47. Wang H, Dymock BW. New patented histone deacetylase inhibitors. Expert Opin Ther Pat. 2009; 19(12):1727-57. 


\title{
Epigenetska terapija kancera
}

\author{
Karmen M. Stankov ${ }^{1}$, Nebojša M. Pavlović ${ }^{2}$, Momir M. Mikov² \\ ${ }^{1}$ Klinički centar Vojvodine, Medicinski fakultet, Univerzitet u Novom Sadu, Novi Sad, Srbija; \\ ${ }^{2}$ Zavod za farmakologiju, toksikologiju i kliničku farmakologiju, Medicinski fakultet, \\ Univerzitet u Novom Sadu, Novi Sad, Srbija
}

\section{KRATAK SADRŽAJ}

Pored genskih alteracija, aberantna epigenetska regulacija ekspresije gena takođe ima značajnu ulogu u razvoju mnogih bolesti, uključujući i maligna oboljenja. U odnosu na normalne ćelije, genom malignih ćelija se odlikuje globalnom hipometilacijom DNK i hipoacetilacijom histona. S obzirom na značaj metilacije DNK i acetilacije histona u inicijaciji i progresiji humanih kancera, ove epigenetske modifikacije su identifikovane kao nove terapijske mete. Imajući u vidu i da su, nasuprot genskim alteracijama, epigenetske promene u malignitetima potencijalno reverzibilne, došlo je do razvoja farmakoloških inhibitora DNK metiltransferaza (DNMT) i histon-deacetilaza (HDAC). Indukovanjem demetilacije DNK i acetilacije histona, ovi lekovi mogu da reaktiviraju prethodno utišane tumor-supresorne gene u malignim ćelijama i tako dovedu do obnavljanja funkcije značajnih ćelijskih signalnih puteva. Još je, međutim, nejasno da li je većina efekata HDAC inhibitora posledica alteracija u acetilaciji histona ili promena u regulatornim ćelijskim putevima dejstvom na nehistonske proteine. DNMT i HDAC inhibitori mogu biti efikasni kao monoterapija, ali je utvrđeno da se veća efikasnost kliničke primene epigenetskih modulatora može dobiti u kombinaciji sa drugim hemoterapeuticima. lako je učinjen značajan napredak $u$ istraživanju epigenomike poslednjih godina, još mnogo toga treba da se razjasni u pogledu uloge epigenoma u procesu karcinogeneze, te su potrebna dalja istraživanja kako bi se obezbedilo dovoljno informacija za optimizaciju epigenetske terapije u kliničkoj praksi. Ključne reči: epigenetika; metilacija DNK; acetilacija; histon-deacetilaza; tumor; inhibitor 